\begin{tabular}{lcr}
\multicolumn{3}{c}{ ANNALES } \\
UNIVERSITATIS MARIAE CURIE-SKŁODOWSKA & \\
LUBLIN - POLONIA & \\
VOL. LXXIII, 1 & SECTIO AA & 2018 \\
\hline
\end{tabular}

\title{
Possibilities of recovery and separation of rare earth elements
}

\author{
Dominika Fila* and Zbigniew Hubicki \\ Department of Inorganic Chemistry, Faculty of Chemistry, \\ Maria Curie-Skłodowska University, \\ Maria Curie-Skłodowska Sq. 2, 20-031 Lublin, Poland \\ *e-mail: dominika.fila@poczta.umcs.lublin.pl
}

\begin{abstract}
Rare earth metals are a group of elements widely used in high technology products. They are included in the group of critical mineral resources for the EU economy. Rare earth elements are found in computers and mobile phones, as well as in low-emission energy technologies. They are also applied in chemical processes as catalysts in the oil refining. Some of them occur even in considerable quantities in the earth's crust but not very often in the concentrations justifying the profitability of their extraction. Additionally, the constantly growing demand and the current market situation cause that alternative resources of rare earth elements recovery are sought after. Therefore, the recovery and separation methods as well as recovery from the secondary sources are becoming more and more important. The following paper presents the possibilities of recovery and separation of rare earth elements from primary and secondary sources.
\end{abstract}

Keywords: rare earth elements, resources, recovery, separation.

\section{INTRODUCTION}

Rare Earth Elements (REE) is the common name of seventeen elements belonging to the groups of lanthanides and scandium. The 
lanthanides include elements with the atomic numbers from 57 to 71 , i.e. from $\mathrm{La}$ to $\mathrm{Lu}$, as well as the scandium group, with scandium (Sc) and yttrium (Y) [1-5]. These elements can be divided into two subgroups: light rare earth elements (LREE) from lanthanum to europium and heavy rare earth elements (HREE) from gadolinium to lutetium along with yttrium. Rare earth elements are relatively more abundant in the earth's crust than the other commonly used elements, but are not concentrated enough to be easily applied. This is due to the similarity of their ionic radii which in turn, causes difficulties in their separation. Geochemical studies have shown that these elements occur in the earth's crust in larger quantities than, for example, bismuth, iodine and silver. Cerium, whose average content is $6.0 \cdot 10^{-3} \%$, is the most widespread in the group of rare earths. In the earth's crust there is more of it than of lead and tin. These elements are present in minerals, such as silicates, oxides, carbonates, phosphates but never occur as pure metals. Silicates represent about $43 \%$ of REE minerals, carbonates about $23 \%$, oxides about $14 \%$ and phosphates about $14 \%$. The total mean content of rare earth elements in the earth's crust is estimated to be $164 \mathrm{ppm}$. Currently, there are more than 250 rare earth minerals, but in most of them the concentration of rare earth elements is very low and ranges from 10 to $300 \mathrm{ppm}$ [6-11].

Due to their unique magnetic, luminescent and electrochemical properties rare earth elements are essential and irreplaceable in technologically advanced industries and are widely used in environmental research. They are mainly applied in metallurgy, electronics, glass and ceramics, petrochemical industry, agriculture, medicine, nuclear energy production as well as renewable energy sources. These metals and their compounds are employed for the production of permanent magnets being part of computer disks, satellite set-top boxes, hybrid car engines, lasers, biodegradable implants and nickel-metal hydride batteries [12-16].

Extensive use of rare earth elements increases their global demand, which in 2010 was estimated at 136000 tons per year, with world production of 133600 tons. According to U.S. Mineral Commodity Summaries from 2018, global mining of rare earths (Fig. 1) is 130000 tons and the total reserves are 120000000 tons $[17,18]$. 




Fig. 1. World production of rare earth elements in different countries (the own elaboration based on [18]).

Currently, China as a global producer of rare earth elements satisfied about $97 \%$ of global demand. The availability of rare earths is declining, mainly due to the costs imposed by the Chinese government in connection with exports and actions against illegal mining operations. The reduction of availability combined with the increase in demand leads to an increase in the prices of rare earth elements. There are around a thousand identified deposits of rare earths in the world, but only a few mines exist. They are Bayan Obo in China, Mountain Pass in the USA and the recently opened Mount Weld in Australia [7,19].

\section{PRIMARY AND SECONDARY SOURCES OF RARE EARTH ELEMENTS}

Among the primary sources of rare earth elements, minerals such as bastnaesite, monazite and xenotime should be mentioned. Bastnaesite of the general formula $(\mathrm{La}, \mathrm{Ce}) \mathrm{CO}_{3} \mathrm{~F}$ and monazite of the formula $(\mathrm{Ce}, \mathrm{La}) \mathrm{PO}_{4}$ are the main sources of the elements belonging to the LREE group, mainly cerium, lanthanum and neodymium. Bastnaesite, a carbonate mineral, contains about $70 \%$ of rare earth oxides. It occurs in igneous and metamorphic rocks and is obtained mainly from the two largest mines in the world, i.e. Mountain Pass in 
the USA and Bayan Obo in China. This ore is processed using various ways, including gravity and magnetic separation, to produce intermediate rare earth concentrates and then purified using solvent extraction as well as selective precipitation [20-22]. Monazite is a mineral from the phosphates group characterized by a slightly larger amount of HREE than LREE. In contrast to bastnaesite, monazite contains a large content of the naturally occurring radio active element, thorium (4-12 wt.\%) and a variable amount of uranium, which is a negative aspect of mining and processing. It occurs all over the world in beach sands and in the Bayan Obo Mine where it is excavated. It is recovered as a by-product during the processing of ilmenite, rutile and zirconium [8,23]. Xenotime of the general formula $(\mathrm{Y}) \mathrm{PO}_{4}$ is the main source of elements from the HREE group, including ytterbium, dysprosium, erbium, terbium and holmium. Its formula results from the large content of yttrium in this mineral. It is a phosphate mineral containing about $67 \%$ rare earth metal oxides. It occurs in Minas Gerais in Brazil, Hittero, Moss pegmatites in Norway, as well as crystalline metamorphic rocks. Xenotime is recovered as a small ore during mining operations of beach sand, mainly from monazite in Brazil, India, South Africa and Australia. Limited research focuses on the extraction of xenotime from monazite by means of flotation and magnetic separation $[20,21,24]$.

The declining sources of primary deposits and difficulty in obtaining them force many countries to look for alternative sources of rare earth elements. In recovery of rare earth metals various types of secondary and waste materials, which are considered as alternative sources, are more and more important. An alternative secondary sources of rare earth elements are magnets, fluorescent lamps, spent nickel-metal hydride batteries, phosphors, phosphogypsum or fly ash from bituminous coal combustion.

Neodymium-iron-boron (Nd-Fe-B) alloys are the basis of magnets commonly known as $\mathrm{NdFeB}$ magnets composed of $\mathrm{Nd}_{2} \mathrm{Fe}_{14} \mathrm{~B}$ matrix containing large amounts of neodymium with small additives of gadolinium, praseodymium, dysprosium and terbium and other elements such as cobalt, titanium, vanadium, niobium, zirconium or molybdenum. The content of neodymium in this magnet is determined to be $24 \%$, whereas dysprosium is less than $5 \%$. This material is found in hard disks, hybrid or electric car engines and other electronic devices such as loudspeakers or cell phones. On 
a global scale, about 600 million hard drives are produced, consuming from about 6000 to 12000 tons of Nd-Fe-B alloys $[25,26]$.

Another alternative source of rare earth elements are fluorescent lamps. These are gas discharge lamps consisting of a glass tube filled with inert gas and coated internally with a phosphor. Longer life of these lamps and low energy consumption significantly increased their use. The fluorescent lamp includes $88 \%$ glass, $5 \%$ metal, $4 \%$ plastic, 3\% fluorescent powder (phosphor) and $0.005 \%$ mercury. The fluorescent powder obtained after lamps treatment contains mainly halophosphates (45 wt.\%), fine particles of glass and silica (20-30 wt.\%), aluminum oxide (12 wt.\%), phosphors (10-20 wt.\%) and residual fraction (5 wt.\%). This powder is used directly in new lamps or it is subjected to the separation process into individual rare earth metals, which is used for further applications [27].

Nickel-metal hydride battery, abbreviated as Ni-MH, is a type of battery in which the cathode is a porous polymer impregnated with a paste containing active nickel compounds $\left(\mathrm{Ni}(\mathrm{OH})_{2} / \mathrm{NiOOH}\right)$ and other additives stabilizing the electrode and improving its conductivity. The anode like the cathode, consists of a porous polymer impregnated with a mixture of many metals which include rare earth elements such as: lanthanum, cerium, praseodymium and neodymium, and other metals mainly iron, nickel, cobalt, copper and zinc, capable of hydrogen storage. To reduce the price of this type of batteries, instead of the rare-earth alloy, a mischmetal (a mixture of light rare earth elements, LREE) is used in a metallic state. Spent batteries contain 36-42\% nickel, 3-4\% cobalt and $8-10 \%$ mischmetal containing lanthanum, cerium, praseodymium and neodymium. Research on the methods of rare earth metals recovery from $\mathrm{Ni}-\mathrm{MH}$ batteries is being carried out [28, 29].

An alternative source of heavy rare earth elements, mainly yttrium and europium are phosphors. Attempts have been made to recycle phosphor in the cathode-ray tubes used in color TVs and CRT monitors of computers. The fluid catalytic cracking (FCC) catalyst widely used in the petrochemical industry is another source containing about $3.5 \mathrm{wt} . \%$ rare earth oxides, mainly lanthanum and a small amount of cerium, praseodymium and neodymium. Optical glass, whose total global production is about 20000 tons per year, is used for the production of camera lenses, microscopes, binoculars or microscopes with the high refractive index and low dispersion. It 
contains more than 40 wt.\% of $\mathrm{La}_{2} \mathrm{O}_{3}$ together with $\mathrm{Y}_{2} \mathrm{O}_{3}$ and $\mathrm{Gd}_{2} \mathrm{O}_{3}$. The recycling of spent optical glasses can contribute to the recovery of approximately 1600 tons per year of rare earth metal oxides $[26,30,31]$.

Alternative waste materials rich in REE are fly ash and slag coming from the bituminous coal combustion. These raw materials contain not only the main slagging components, i.e. aluminum, iron, silicon, calcium compounds in various proportions, but also other compounds, for example rare earth elements, such as lanthanum, cerium, neodymium and yttrium. Particularly rich in REE are bituminous coals from Russian and Chinese deposits. The sources of these metals in the national bituminous coal deposits are estimated to be 1400 tons, and the average total REE content is $114 \mathrm{ppm}$ [31-34].

\section{SEPARATION OF RARE EARTH ELEMENTS FROM DIFFERENT SOURCES}

After proper preparation and processing of primary or secondary sources of rare earth elements, they are subjected to hydrometallurgical treatment using strongly acidic or alkaline solutions for selective dissolution and precipitation of valuable metals. A variety of procedures are used for the separation of rare earths using the differences in physical and chemical properties of both simple compounds and complexes. Typically, separation methods of rare earths are divided into two groups. The first group includes fractional crystallization, fractional precipitation or oxidation and reduction methods. The second group includes physicochemical methods, such as solvent extraction or ion exchange. They are considered to be excellent methods of metal separation with similar physicochemical properties.

Many scientists have focused on recycling REE from Ni-MH batteries by acid leaching with $\mathrm{H}_{2} \mathrm{SO}_{4}$ or $\mathrm{HCl}[29,35-42]$. Lyman and Palmer [43] investigated recovery of REE from spent Ni-MH batteries using different acids $\left(\mathrm{HCl}, \mathrm{H}_{2} \mathrm{SO}_{4}, \mathrm{HNO}_{3}\right)$ and found that $4 \mathrm{M} \mathrm{HCl}$ is the optimum to achieve maximum amounts of REE after leaching. The hydrometallurgical process of recovery and separation of nickel, cobalt and REE from Ni-MH accumulators has been developed [44]. The electrode material was dissolved in the $2 \mathrm{M} \mathrm{H}_{2} \mathrm{SO}_{4}$ solution or 
$3 \mathrm{M} \mathrm{HCl}$ solution at $368 \mathrm{~K}$. Rare earth elements were separated from the leached solution by solvent extraction using 25\% D2EHPA in kerosene, and then these elements were separated from the organic solution and precipitated using oxalic acid. Provazi et al. [45] reported the recycling of various metals, including $\mathrm{Ce}$ and $\mathrm{La}$, from a mixture of different types of batteries in 2011. Umicore and Rhodia developed in 2011 a recycling process for REE from Ni-MH batteries $[46,47]$.

Jiang et al. [48, 49] described a hydrometallurgical process for the recovery of rare earth metals from spent borosilicate optical glass containing 43.12 wt. $\%$ of $\mathrm{La}_{2} \mathrm{O}_{3}, 9.37$ wt. $\%$ of $\mathrm{Y}_{2} \mathrm{O}_{3}$ and $4.60 \mathrm{wt} . \%$ of $\mathrm{Gd}_{2} \mathrm{O}_{3}$. The optimized process involved the conversion of rare earth metals contained in glass to insoluble rare earth hydroxides using the hot concentrated $\mathrm{NaOH}$ solution (55 wt.\%) at $413 \mathrm{~K}$ and then leaching rare earth hydroxides with the hot $6 \mathrm{M} \mathrm{HCl}$ solution at temperature above $363 \mathrm{~K}$, obtaining an aqueous solution of rare earth chlorides. The REE recovery amounted $99.4 \%$ for La, $100 \%$ for $\mathrm{Y}$ and $100 \%$ for $\mathrm{Gd}$. The other studies have shown that selective leaching of neodymium from the roasted $\mathrm{NdFeB}$ magnets was possible using $0.02 \mathrm{M} \mathrm{HCl}$ in an autoclave at $453 \mathrm{~K}$. Over $80 \%$ of neodymium and dysprosium appeared in the leach solution [50].

Solvent extraction is a classic technique used mainly to separate individual metals from a mixture of compounds. Depending on the extraction mechanism associated with the type of complex that forms in the organic phase, cationic, anionic and solvating extractants are distinguished. These include di-(2-ethylhexyl)phosphoric acid (D2EHPA), bis(2,4,4 trimethylpentyl)phosphinic acid (Cyanex 272), tri-n-butyl phosphate (TBP), 2-ethylhexyl 2-ethylhexyl phosphate (PC88A), neodecanoic acid (Versatic 10) and tricaprylylmethylammonium chloride (Aliquat 336) [51-54]. Shimizu et al. [55] conducted REE recovery from the used fluorescent lamps by means of supercritical extraction with carbon dioxide and a mixture of nitric acid solution(V) with tri-n-butyl phosphate (TBP). Over $99.5 \%$ of yttrium and europium present in the mixture was extracted after 2 hours of leaching at $15 \mathrm{MPa}$ and a temperature of $333 \mathrm{~K}$. Extraction was also carried out using a $\mathrm{TBP} / \mathrm{HNO}_{3} / \mathrm{H}_{2} \mathrm{O}$ mixture at atmospheric pressure. However, a lower extraction efficiency of $40 \%$ for europium and yttrium was obtained. Banda et al. [56] performed a solvent extraction to separate La from a solution containing Pr and $\mathrm{Nd}$ and they used D2EHPA, Cyanex 272, Cyanex 301 and PC88A as 
extractants. Cyanex 272 has been shown to have the best properties of selective separation of $\mathrm{La}$ from $\mathrm{Pr}$ and $\mathrm{Nd}$ among the tested extractants at an initial $\mathrm{pH}$ of 4.94. The percentage of La, Pr and Nd extractions with Cyanex 272 was 4.9\%, 96.6\% and 98.7\%, respectively.

The ion exchange is an extremely effective process for obtaining rare earth metals of high purity. During the ion exchange process, various cationic or anionic ion exchangers are used to extract metals from the leach solutions. The affinity of exchanged ions for the ion exchangers depends mainly on the ion size and charge. Ion exchangers have generally higher selectivity for ions with the increasing valency or charge. Among the ions with the same charge there is a greater affinity for those with a higher atomic number. Many researchers have focused on rare earth metal recovery studies using various types of ion exchange resins, such as Tulsion $\mathrm{CH}-96$, Tulsion CH-93, T-PAR and IR-120P. Kumar et al. [57] conducted a solid-liquid extraction of rare earth elements such as Tb, Dy, Ho, Y, $\mathrm{Er}, \mathrm{Yb}$ from the phosphoric acid(V) solutions using the Tulsion $\mathrm{CH}-96$ and T-PAR resins. On the basis of the obtained results, they found the possibility of using the Tulsion $\mathrm{CH}-96$ resin in the Lu separation process from the $\mathrm{Tb} / \mathrm{Dy}$ system and $\mathrm{Yb}$ from the $\mathrm{Tb} / \mathrm{Dy}$ system, as well as Tb/Dy separation from the phosphoric acid(V) solution containing Lu or $\mathrm{Yb}$. Wang et al. [58, 59] investigated the extraction of rare earth elements from the hydrochloric acid solutions using the extractive ion exchangers containing Cyanex 272 and the extractive resin containing 1-hexyl-4-ethyloctyl isopropylphosphonic acid (HEOPPA). Adsorption of rare earth elements on this type of ion exchangers as a function of $\mathrm{pH}$ was in the order of: $\mathrm{Lu}(\mathrm{III})>\mathrm{Yb}$ (III) $>\mathrm{Tm}(\mathrm{III})>\operatorname{Er}(\mathrm{III})>\mathrm{Y}(\mathrm{III})>\mathrm{Ho}(\mathrm{III})$. Preconcentration and separation of $\mathrm{La}(\mathrm{III}), \mathrm{Nd}(\mathrm{III})$ and $\mathrm{Sm}$ (III) from the synthetic solution were also carried out using Amberlite XAD-4 with crown ether (dibenzo-18crown-6). The adsorbed rare earths were washed with $2 \mathrm{M} \mathrm{HCl} \mathrm{[60].}$

The recovery and separation of rare earth elements can also be made by means of a precipitation process using various precipitating agents, such as oxalic acid, sodium sulfate, sodium hydroxide or ammonia. Innocenzi and Vegliò [61] conducted a selective precipitation of the solution after sulfuric acid leaching of spent $\mathrm{Ni}-\mathrm{MH}$ batteries using sodium hydroxide. 99\% recovery of rare earth elements at $\mathrm{pH}<2$ was obtained. A sediment composed of about $64 \%$ of lanthanum sulfate and $28 \%$ of cerium sulfate was prepared. In the 
paper [62] by Soe et al., ammonium hydroxide was used to precipitate lanthanum from monazite originating from Moemeik Myitsone. The lanthanum was precipitated in the form of hydroxide at $\mathrm{pH}$ values ranging from 7.9 to 9.6. Precipitation resulted in recovery of about $96 \%$ of lanthanum oxide.

Depending on the composition of the separated mixture, combination of several methods is used, selecting the separation technology for the type of used raw material. The use of combined methods makes it possible to obtain rare earth metals with the highest degree of purity.

\section{CONCLUSIONS}

Rare earth elements are key materials for many developing technologies and products. A significant part of them is associated with the so-called green technologies that are to reduce the negative impact of the economy on the environment. The examples include alternative energy sources and electric vehicles. Due to the observed and predicted increase in the REE demand and the centralization of production of these materials in China, there is concern about their supply stability. Recycling of rare earths can play an essential role in solving a number of problems related to these elements, including satisfying the increased demand, increasing their security of supply and overcoming the problem of the balance between the demand for rare earths and their extraction from primary sources from the mine. There is a considerable REE recycling potential from such products as permanent magnets, fluorescent lamps, batteries and catalysts, however, in all these areas a significant amount of research is needed to increase its effectiveness.

\section{REFERENCES}

[1] J.B., Hedrick, in: Rare earths. The lanthanides, yttrium and scandium, U.S. Department of the Interior, Bureau of Mines, Washington, 1993.

[2] W. Charewicz, in: Pierwiastki ziem rzadkich, WNT, Warszawa, 1990.

[3] W. Roberts, T. Campbell, Jr. G. Rapp, in: Encyclopedia of minerals, Reinhold, New York, 1990. 
[4] J.B. Hedrick, D.A. Templeton, in: Rare earth minerals and metals 1989, Bureau of Mines, Minerals Yearbook, 1991.

[5] R.K. Duncan, in: Geology and mineralisation of the Mt. Weld Rare Earth Deposit, Laverton, Western Australia, 1992.

[6] J. Kowalczyk, C. Mazanek, in: Metale ziem rzadkich i ich zwiqzzki, WNT, Warszawa, 1989.

[7] A. Jordens, Y.P. Cheng, K.E. Waters, Miner. Eng., 41, 97-114, (2013).

[8] C.K. Gupta, N. Krishnamurthy, in: Extractive Metallurgy of Rare Earths, CRC Press, NY, USA, 2005.

[9] A. Kumari, R. Panda, M.K. Jha, J.R. Kumar, J.Y. Lee, Miner. Eng., 79, 102-115, (2015).

[10] J. Zhang, C. Edwards, in: 44th Annual Meeting of the Canadian Mineral Processors, CIM, Ottawa, pp. 79-102, 2012.

[11] A. R. Chakhmouradian, F. Wall, Elements, 8, 333-340, (2012).

[12] G. Charalampides, K.I. Vatalis, B. Apostoplos, B. Ploutarch-Nikolas, Procedia Econ. Financ, 24, 126-135, (2015).

[13] S. Massari, M. Ruberti, Resour. Policy, 38, 36-43, (2013).

[14] A. Akah, J. Rare Earths, 35, 941-956, (2017).

[15] K.A. Gschneidner, Mater. Matters, 6, (2011).

[16] B. Zhou, Z. Li, C. Chen, Minerals, 7, 1-14, (2017).

[17] M. Panayotova, V. Panayotov, Min. Miner. Process., 55, 142-147, (2012).

[18] U.S. Geological Survey, in: Mineral commodity summaries 2018: U.S. Geological Survey, https://doi.org/10.3133/70194932, 2018.

[19] U.S. Geological Survey, in: The Rare-Earth Elements-Vital to Modern Technologies and Lifestyles, https://doi.org/10.3133/fs20143078, 2014.

[20] A. Jordens, Y.P. Cheng, K.E. Waters, Miner. Eng., 41, 97-114, (2013).

[21] Z. Chen, J. Rare Earths, 29, 1-6, (2011).

[22] P. Rydel, M. Nowak, Przegląd Geol., 63, 348-362, (2015).

[23] V. Kumar, M.K. Jha, A. Kumari, R. Panda, J.R. Kumar, J.Y. Lee, in: EPD Congress-2014, San Diego, California. USA, 2014.

[24] K.R. Long, B.S. Van Gosen, N.K. Foley, D. Cordier, in: U.S. Geological Survey Scientific Investigations Report 2010-5220, Reston, VA, USA, pp. 1-104, 2010.

[25] O. Gutfleisch, M.A. Willard, E. Bruck, C.H. Chen, S.G. Sankar, J.P. Liu, Adv. Mater., 23, 821-842, (2011).

[26] K. Binnemans, P.T. Jones, B. Blanpain, T.V. Gerven, Y. Yang, A. Walton, M. Buchert, J. Clean. Prod., 51, 1-22, (2013).

[27] K. Binnemans, P.T. Jones, J. Rare Earths, 32, 195-200, (2014).

[28] T. Muller, B. Friedrich, J. Power Sources, 158, 1498-1509, (2006).

[29] S. Luidold, H. Antrekowitsch, PATENT, EP 2444507 A1, 25.04.2012. 
[30] M. Tanaka, T. Oki, K. Koyama, H. Narita, T. Oishi, Handbook on Physics and Chemistry of Rare Earths, 255, 159-211, (2013).

[31] A. Jarosiński, in: Wybrane zagadnienia z technologii pozyskiwania metali ziem rzadkich, Wydawnictwo IGSMiE PAN, Kraków, 2016.

[32] V.V. Seredin, S. Dai, Int. J. Coal Geol., 94, 67-93, (2012).

[33] J. Całus-Moszko, B. Białecka, Gospodarka Surowcami Mineralnymi Mineral Resources Management, 29, 67-80, (2013).

[34] A. Jarosiński, Zeszyty Naukowe Instytutu Gospodarki Surowcami Mineralnymi i Energią Polskiej Akademii Nauk, 92, 75-88, (2016).

[35] N. Tzanetakis, K. Scott, J. Chem. Technol. Biot., 79, 919-926, (2004).

[36] A. Poscher, S. Luidold, H. Antrekowitsch, in: Seltener Erden, pp. 419426, 2011.

[37] J.M. Nan, D.M. Han, M.J. Yang, M. Cui, X.L. Hou, Hydrometallurgy, 84, 75-80, (2006b).

[38] J.M. Nan, D.M. Han, M.J. Yang, M. Cui, J. Electrochem. Soc., 153, 101105, (2006a).

[39] L. Pietrelli, B. Bellomo, D. Fontana, M.R. Montereali, Hydrome-tallurgy, 66, 135-139, (2002).

[40] L. Pietrelli, B. Bellomo, D. Fontana, M. Montereali, Waste Manag., 25, 221-226, (2005).

[41] L.E.0.C. Rodrigues, M.B. Mansur, J. Power Sources, 195, 3735-3741, (2010).

[42] [42] M. Kaindl, S. Luidold, A. Poscher, Berg-Huettenmaenn, Monatsh, 157, 20-26, (2012).

[43] J.W. Lyman, G.R. Palmer, Hydrometallurgical treatment of nickelmetal hydride battery electrodes, in: Third International Symposium on Recycling of Metals and Engineered Materials, Point Clear, Alabama (USA), pp. 131-144, 1995.

[44] P.W. Zhang, T. Yokoyama, O. Itabashi, Y. Wakui, T.M. Suzuki, K. Inoue, J. Power Sour., 77, 116-122, (1999).

[45] K. Provazi, B.A. Campos, D.C.R. Espinosa, J.A.S. Tenorio, Waste Manag., 31, 59-64, (2011).

[46] Rhodia, Chem. Eng. News, 89, 16, (2011).

[47] Rhodia, Press Release: Umicore and Rhodia Develop Unique Rare Earth Recycling Process for Rechargeable Batteries, 2011.

[48] Y.R. Jiang, A. Shibayama, K. Liu, T. Fujita, Can. Metall. Q., 43, 431-438, (2004).

[49] Y.R. Jiang, A. Shibayama, K.J. Liu, T. Fujita, Hydrometallurgy, 76, 1-9, (2005).

[50] K. Koyama, A. Kitajima, M. Tanaka, Kidorui, 54, 36-37, (2009).

[51] C. Gupta, N. Krishnamurthy, Int. Mater. Rev., 37, 197-248, (1992).

[52] N. Thakur, Miner. Process. Extract. Metall. Rev., 21, 277-306, (2000). 
[53] H.S. Yoon, C.J. Kim, K.W. Chung, S.D. Kim, Hydrometallurgy, 165, 2743, (2016).

[54] A. El-Kot, J. Radioanal. Nucl. Chem., 170, 207-214, (1993).

[55] R. Shimizu, K. Sawada, Y. Enokida, I. Yamamoto, J. Supercrit. Fluid, 33, 235-241, (2005).

[56] R. Banda, H.S. Jeon, M.S. Lee, Hydrometallurgy, 121-124, 74-80, (2012).

[57] B.N. Kumar, S. Radhika, B.R. Reddy, Chem. Eng. J., 160, 138-144, (2010).

[58] Z. Wang, G. Ma, D. Li, Solvent Extr. Ion Exch., 16, 813-828, (1998).

[59] Z.H. Wang, G.X. Ma, J. Lu, W.P. Liao, D. Li, Hydrometallurgy, 66, 95-99, (2002).

[60] S.R. Dave, H. Kaur, S.K. Menon, React. Funct. Polym., 70, 692-698, (2010).

[61] V. Innocenzi, F. Vegliò, J. Power Sources, 211, 184-191, (2012).

[62] N.N. Soe, L.T. Shwe, K.T. Lwin, World Acad. Sci. Eng. Technol., 2, 126129, (2008). 